\title{
Biskop Balslevs bøger i hertugdømmet Slesvig
}

\author{
Af Poul Kürstein.
}

Også vi af den nulevende slægt kender biskop Balslevs lærebøger, nogle af de hyppigst trykte bøger i Danmark; men da Carl Frederik Balslev skrev dem, var det til brug for hans egne børns undervisning, og han var da ikke biskop, men sogneprest i Vejerslev og Blidstrup sogne på Mors. Hans "Bibelhistorie tilligemed Lidet af Kirkens Historie efter Apostlenes Dage. Til Brug for Almueskoler. Med 1 Landkort « udkom i København i 1846, og hans "Luthers Catechismus med en kort Forklaring. En Lxrebog for den uconfirmerede Ungdom « udkom samme sted i 1849 . I 1850 blev han stiftsprovst i Ribe, og biskop i samme by blev han først i 1867 . Han var just i færd med at resignere, da døden hentede ham i Ribe den 11. marts 1895.

Ligesom hans forgænger $\mathrm{i}$ embedet Hans Adolph Brorson ikke blev biskop udelukkende på grund af salmen $\gg \mathrm{Op}$ al den ting, som Gud har gjort«, er Balslev næppe heller blevet biskop bare på sine beger, men de har nok bidraget ikke uvæsentligt til hans ry som praktisk kirkemand. Bøgerne blev begge autoriseret til brug i skolerne i kongeriget og kom i mange oplag, først et oplag om året, siden endnu flere. Bibelhistorien udkom, så vidt vides, sidste gang i 1954 i 149. oplag, katekismens sidste oplag kom i 1965 og var det 345.! Mon nogen anden dansk bog efter Bibelen har været mere udbredt? Katekismen er blevet båret videre på Luthers stærke vinger, og det er ikke sagt, at Balslevs udgave af den nu er færdig.

Som det er fremhævet af $\mathrm{H}$. Hejselbjerg Paulsen i Sonderjyske Årbøger 1961, kunne en dansk skolebog ikke uden videre bruges i Sønderjylland før 1848. Efter 1850 så det ganske anderledes ud. Dels kom der tyske oversættelser af begge Balslevs bøger, som blev 
hjulpet frem af de kirkelige myndigheder ved gode anbefalinger, dels foreligger der direkte udsagn fra provst C. C. J. Asschenfeldt om, at regeringen agtede at indføre bogen både $i$ dens danske og $i$ dens tyske skikkelse $i$ hele hertugdømmet. Om bogens brug taler antallet af oplag af disse tyske oversættelser.

Det kan ikke nøjagtig siges, hvor mange oversxttelser og hvor mange oplag der har været, fordi Dansk Bogfortegnelse er yderst mangelfuld, når det drejer sig om bøger trykt i Sønderjylland, og også fordi vore biblioteker er dårligt forsynet med dem. Ejere af disse bøger ville gøre en god gerning ved at skænke dem til Dansk Centralbibliotek i Flensborg. Vi kender - men ejer ikke! - følgende:

Luthers Katechismus mit einer kurzen Erklärung. Ein Lehrbuch für die unconfirmirte Jugend, von C. F. Balslev, Stiftsprobst und Hauptpastor an der Domkirche in Ripen. Aus dem Dänischen übersetzt nach der zweiten Auflage. Mit einem Vorworte von dem interimistischen Superintendenten Asschenfeldt, R. v. D., Flensburg 1852. In Commission bei J. F. Grün, Angelburgerstraße. Druck von J. C. Schwensen in Eckernförde. $78 \mathrm{~s}$.

Det er påfaldende, at oversætteren ikke er næunt hverken på titelbladet eller i Asschenfeldts forord, men bogen udkom i en ny udgave, hvor også oversætteren var nævnt:

Luthers Katechismus, mit einer kurzen Erklärung. Ein Lehrbuch für die unconfirmirte Jugend von C. F. Balslev, Stiftsprobst und Hauptprediger an der Domkirche in Ripen. Aus dem Dänischen übersetz nach der zweiten Auflage von P. C. Grün, Lehrer der Oberclasse am Königl. Erziehungsinstitut für Soldatenkinder in Eckernförde. Mit einem Vorworte von dem interimistischen Superintendenten Asschenfeldt, R. v. D. Zweite, revidierte Auflage. Schleswig, 1854. J. Neddermeyer's Buchhandlung. Gedruckt im Königl. Taubst.-Institut.

C. C. J. Asschenfeldts forord er tids- og stedfæstet til »Flensburg im Christfeste 1851 «, altså i julen. Det er enslydende i begge udgaver, og af forordet fremgår det, at Balslevs lærebog i den danske original, som er Asschenfeldt særlig kær, i stort omfang bruges af præster og skolelærere i den nordlige del af Slesvig, fordi den ved sit sunde, klare og kristelige indhold har skaffet sig indgang. Asschenfeldt har selv revideret Grüns tyske oversættelse, som vil tage hensyn til det tyske ore. Han foreslår præsterne og skolelærerne, at de skal gennemtrække bogen med hvide blade, hvor de kan skrive op, hvad der ellers kan tjene til at gøre bogen nyttig, og onsker, at bogen må finde den fortjente anerkendelse og modtagelse, 
C. F. Balslev, 1805-95,

fotograferet 1872 .

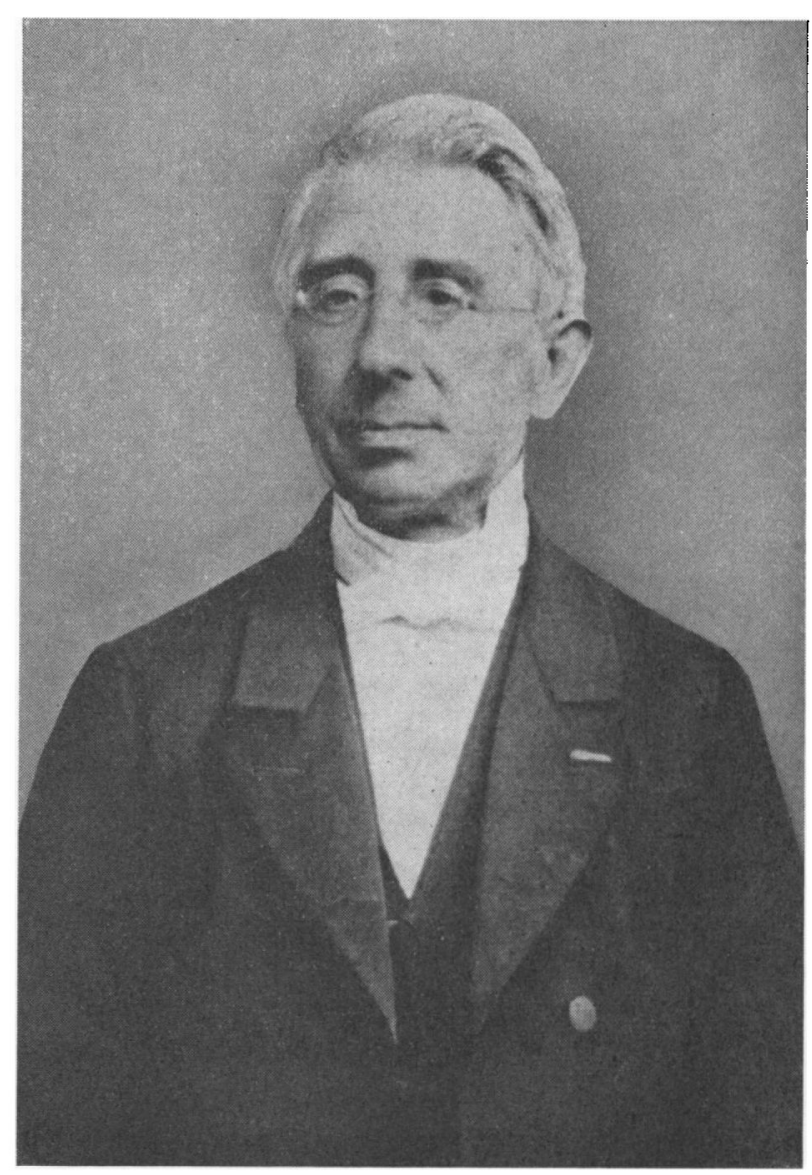

$\mathrm{da}$ det er det kongelige ministeriums hensigt at indføre den $\mathrm{i}$ hele hertugdømmet. Asschenfeldt var hovedpræst, førstepræst ved St. Nikolaj kirke i Flensborg, provst for staden Flensborg og Flensborg provsti, interimistisk, d. v.s. foreløbig superintendent, biskop og ridder af Dannebrog.

Om oversætteren, Peter Christian Grün, skriver Asschenfeldt, at han er "en dygtig og trosindet skolemand «. Det var han, og det blev han.

Peter Christian Grün var født i Flensborg den 25. juni 1820 i St. Johannes sogn, men hans fader, kur- og fanesmed, senere dyr- 
læge Johann Gottlieb Grün, var født i Berlin som søn af en kurog fanesmed ved Garde du Corps og har altså været født preussisk undersåt. Han døde højt bedaget, 95 år gammel, i Flensborg. Hans moder hørte derimod til landets dotre. Hun hed Dorothea Christine Mangelsen og var fra Sørup. Så der er ikke årsag til at grunde over nogen modsætning i Grüns afstamning og klare danske sindelag. I disse tider var det i øvrigt ikke ualmindeligt, at indvandrede tyskere blev gode danske mænd og kvinder. Det er endog et særligt flensborgsk træk. Grün tog lærereksamen fra Skårup i 1841, og i 1844 blev han hjælpelærer i Pommerby i Gelting sogn og giftede sig samme àr med en lærerdatter, hvorved han blev svoger til degn og lærer C. E. L. Schlesinger i Adelby, en god dansk mand også han, hvis sønnedatter Marianne Schlesinger blev lærerinde ved Duborg-Skolen omtrent fra dens start. I 1847 blev Grün lærer i Barkelsby i Borreby sogn på Svansø.

Her må han under de meget vanskelige forhold under oprøret og krigen 1848-50 have holdt sig som en god dansk mand, for dels bliver han i 1851 udnæunt til lærer ved Christians Plejehus i Egernførde, dels modtages han af meddeleren til "Altonaer Mercur« med særdeles stor betænkelighed.

Det næste, vi hører til ham, er den navnløse overættelse af Balslevs katekismus (1852).

Det var praktisk for Grün at få sin bog trykt i Egernførde af hensyn til korrektur og andre ting, der følger med tryk. J. C. Schwensens troskab er der heller ingen grund til at drage $\mathrm{i}$ tvivl. Han udgav senere Eckernförde Zeitung. Det var endnu mere praktisk for Grün at have en broder i Flensborg, der var bogbinder, nemlig den Johann Friedrich Grün i Angelbogade, som nævnes på titelbladet til 1. udgave, for her i Flensborg med de store, børnerige sogne med tysksprogede skoler skulle han søge sine fleste kunder.

Bogen må være blevet godt modtaget, og da oplaget vel næppe har været alt for stort, eftersom Grün nok har udsendt bogen på egen bekostning og vel nok i fællig med broderen, er den også hurtigt blevet udsolgt. Det fremgår af, at 2. udgave udkommer i 1854 i $x$ ndret form. Foruden Asschenfeldts forord er der nu én ting til, der tyder på, at bogen er ved at blive officiel. Den trykkes ikke længere på det lille trykkeri i Egernførde, men på Det konge- 
P. C. Grün.

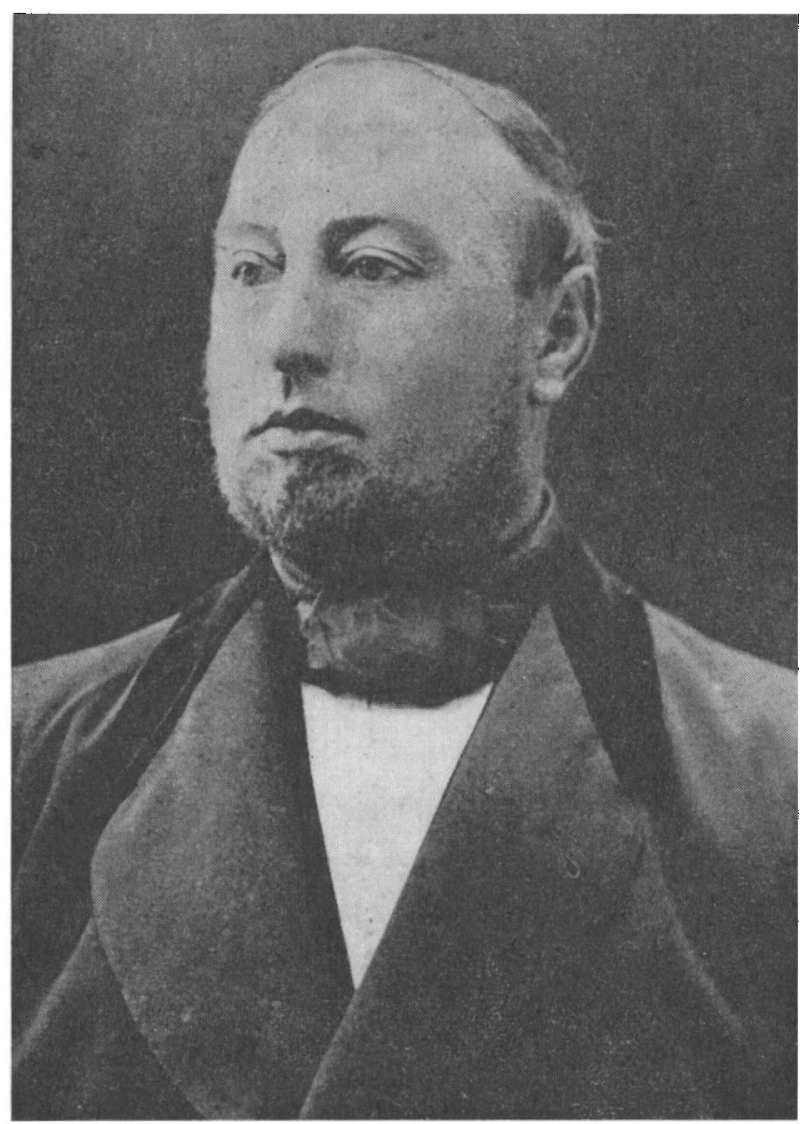

lige Døvstumme-Instituts trykkeri i Slesvig. Om bogens anseelse taler endvidere, at Grün nu anfører både sit navn og sin anselige titel på titelbladet.

Oplaget kan heller ikke have været alt for lille, for der gik 5 år, inden et nyt oplag kom fra trykken, men da var Grün ikke med langere. Det drejede sig om:

Luthers Katechismus mit einer kurzen Erklärung. Ein Lehrbuch für die unconfirmirte Jugend von C. F. Balslev, Stiftspropst und Hauptprediger in Ribe, R. v. D. Auf Veranstaltung des Königlichen Ministeriums für das Herzogthum Schleswig zum Schulgebrauch neu übersetzt. Preis ungebunden $10 \mathrm{~B}$, gebunden $16 \mathrm{~B}$. Schleswig. Im Verlag der Waisenhäuser zu Schleswig, Flensburg und Tondern. 1859. 76 sider. 


\section{Rutbero $\mathfrak{A}$ atedía \\ mit cince furzen Conflärumg.}

\section{(Eiil febrbud)}

für bie unconîrmirte Juggend, von

(5. F. Balalev,

Stiftäprobif uno Şauptpafter an Der Demfirde in Ripent.

24us Dem Danifhen

überfeķt nad) ber zweiten Pluflage.

\section{Mit cittem 30 orworte}

von

Sen interimiftiden Superintenbenten

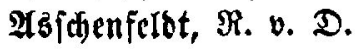

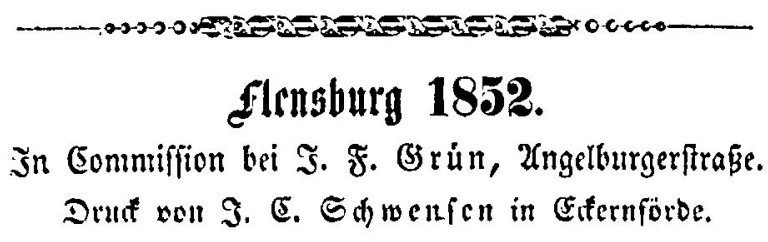

På bagsiden af titelbladet er trykt $\mathrm{i}$ forkortet form det allerhøjeste privilegium af 20 . februar 1859 , som giver de tre vajsenhuse eneret på tryk og salg af denne bog med trussel om straf $i$ form af 
konfiskation og en vilkårlig bøde for den, der handler imod dette privilegium.

Trykkeriet er ikke angivet på eksemplaret i Statsbiblioteket i Århus, men er vel snarest Det kongelige Døvstumme-Instituts trykkeri i Slesvig. Typerne er de samme som i Grüns 2. udgave 1854. I 1861 udkom et nyt oplag, hvor kun årstallet på titelbladet er ændret. Sandsynligvis er stående sats blevet brugt, måske endda stereotypisats.

Det er altså fjerde gang på niende år, at Balslevs katekismus udkom på tysk $\mathrm{i}$ hertugdømmet Slesvig, til trods for, at den kun blev brugt $\mathrm{i}$ hertugdømmets tyske skoler, nemlig i sognene i Jernved eller Danske Skov, på Femern, på Svansø, i Sønder Angel syd for Oksbrekken, i landet syd for Danevirke, i Ejdersted og i Frisland vest for Svesing, Olderup, Fjolde og Hjoldelund sogne og i byerne Flensborg, Slesvig, Tønning, Garding og Egernførde samt i flækkerne Arnæs, Kappel og Svavsted.

Dermed var P. C. Grün gået ud af Balslev-katekismens historie, men ingenlunde ud af sagaen. Samme àr som 2. udgave af katekismen fik han en stor og selvstæendig bog ud:

Das Vaterland, ein Lesebuch für die oberen Classen der Volksschule von P. C. Grün, Lehrer der Oberclasse am Königl. Erziehungsinstitut für Soldatenkinder in Eckernförde. Altona. Verlag von A. Lehmkuhl \& Comp. 1854. 588 sider.

Bogens titel er taget fra W. J. G. Curtmanns tyske læsebog, og den er gjort "til samme formål for vort fedreland som hin for Tysklandk. "Af vore to anerkendt bedste lasebøger, Dr. Harms' "Gnomon« og $\mathrm{H}$. Burgwardts "Bildungsfreund «, har den sidste måttet opgive sin strålende løbebane, da fædrelandet blev den for trangt, og den forste har aldrig fundet almindelig udbredelse $\mathrm{i}$ hertugdømmet Slesvig «. Sådan hedder det i forordet, og oplysningen om, at Harms' „Gnomon " ikke har været særligt udbredt, er meget interessant. Burgwardts bog var yderst tysk og et af de forste eksempler på, at en skolebog har været anvendt til nationalpolitisk propaganda. Det er tydeligt, at Grüns bog er tænkt som modgift mod slesvig-holstenske tendenser: "To halvøer og en øgruppe med flere spredt liggende øer .... udgør det større fædreland. Den skandinaviske halvø hedder den ene, den cimbriske halvø den anden, og øgruppen hedder: den danske. Denne danner sammen med den 
cimbriske halvø i det større fædreland, hvis fællesnavn er Skandinavien, vort snævrere fædreland:

\section{DANMARK.}

"Meerumschlungen « havomfavnet er det, $\mathrm{i}$ ordets egentlige betydning, både helheden og de enkelte dele.«

Senere var Grün lærer flere steder. Han endte som degn og lærer i Ulsnæs ved Slien 1863-88. Tilsyneladende er det mærkeligt, at denne gode danske mand ikke blev fjernet fra sit embede i 1864, men hernede gik stormene ikke så stærkt som oppe i sprogreskripternes område. Måske kunne den lige så dansksindede pastor Augustiny i Ulsnæs, som med en smule vanskelighed klarede at blive i sit embede, også gøre noget for sin dygtige lærer og degn. Måske er det ikke uden forbindelse med P. C. Grüns danske indstilling, at alle hans børn udvandrede til Amerika. Han begravede sin hustru i Flensborg i 1895, men han er ikke selv død her og heller ikke i Ulsnæs eller noget andet sted i Sønder Angel. Måske er han død i Amerika. Broderen derimod, J. F. Grün, blev i Flensborg, og i 1869-70 finder vi ham i frimurerlogen "Wilhelm zur nordischen Treue«, som var fuld af preussiske officerer og embedsmænd og heller ikke savnede en insurgent-officer, Zeska, fra 1848 blandt sine brødre! Her var en ganske anden ånd. J. F. Grüns søn sadlede om og købte firmaet Hansen-Rum, og både det og slægten blomstrer i Flensborg den dag i dag.

Også Balslevs bibelhistorie kom på tysk, men lidt senere, og med den og med Grüns katekismus fortsatte Flensborg sin tradition som forlægger- og trykkested for fremragende danske værker, som skulle forelægges et tysk publikum, med "Herrn Ludwig Holbergs Dänische Reichs-Historie ins Deutsche übersetzt « $1743 \mathrm{ff}$ som vel fornemste eksempel. Bibelhistorien hed på tysk:

Die Biblische Geschichte sammt einem kurzen Abrisz der Kirchengeschichte der nachapostolischen Zeit. Von C. F. Balslev, Stiftspropst und Prediger an der Domkirche in Ripen. Nach der sechsten Auflage, und mit Bewilligung des Verfassers aus dem Dänischen übersetzt von Dr. A. F. Thomsen, Cand. des heil. Predigtamts. Flensburg, 1854. Verlag von N. A. Sundby. Kastrup's Buchdruckerei. 128 sider, 1 farvetrykt kort.

Asmus Friedrich (Hübner-) Thomsen var født i Flensborg 26. august 1823, blev student i Kiel 1842 og dr. phil. i Jena og teologisk kandidat i Flensborg 1853. Oversxttelsen har han gjort, mens han ventede på embede, men vi ved kun, at han først fik embede og 
endda kun som konstitueret rektor i Heide i Holsten 1858, hvad han var, til han blev institutbestyrer $i$ Kappel 1863. Men året efter oprandt en gylden tid for embedsløse kandidater til det hellige præsteembede, for i 1864 blev næsten alle præster fordrevet, og Thomsen kom i pastor Meiers sted i Kejtum, hvor han virkede til sin død den 30. april 1887. N. A. Sundby, forlæggeren, var Gustav Johannsens formand som dansk boghandler og forlægger i Flensborg, men hverken han eller oversætteren har fået al for megen glxde af deres bibelhistorie. Kun 4 år fik de til at sælge den i, for så kom den ud for en privilegeret udgave, som ingen kunne hamle op med:

Biblische Geschichte nebst einigen Zügen aus der Geschichte der Kirche nach den Zeiten der Apostel. Auf Veranstaltung des Königlichen Ministeriums für das Herzogthum Schleswig zum Schulgebrauch neu übersetzt nach dem dänischen Original von Balslev, Stiftspropsten in Ribe, R. v. D. Mit einer Karte. Preis ungeb. 24 B, geb. 30 B. Schleswig, 1858. Im Verlag der Waisenhäuser zu Schleswig und Tondern. $128+4$ sider.

Kortet går over 2 sider og er litograferet i farver, "Lith. Ausf. v. F. Eckener, Schleswig«. Trykkeriet er ikke angivet på eksemplaret i Statsbiblioteket i Århus, men er vel Det kongelige DøvstummeInstituts trykkeri i Slesvig at dømme efter satsen.

Bag på titelbladet er anført indholdet af det Allerhøjeste privilegium på eneret for tryk og forlag for vajsenhusene af 20. februar 1858.

Selve bogen går fra side 1 til 128, hvortil der påfaldende nok er tilføjet »Inhalt « på side 115, 114, 115, 116 (sic!), selv om disse sidetal også findes på deres rette plads i selve bogen.

$\mathrm{Da}$ ministeriet for hertugdømmet Slesvig udtrykkelig havde nævnt sig selv på titelbladet og efter gammel skik og ret havde givet vajsenhusene privilegium på udgivelsen, var både Balslevs tyske katekismus og hans tyske bibelhistorie tilstrækkeligt autoriseret til brug i skolerne, og oplagenes tal viser da også, at de har været brugt.

Hejselbjerg Paulsens fortjenstfulde afhandling om gamle skolebøger i Sønderjyske Årbøger 1961 nævner 2 tilfælde, i Øsby og Bjolderup, hvor man nægtede at bruge den danske Balslev, og denne vægring făr desværre lov til at give det hovedindtryk, at den danske Balslev ikke har varet brugt i Nordslesvig. Dette er ikke rigtigt. Vi har provst Asschenfeldts udtrykkelige ord for, at "den bruges i stort omfang i det nordlige Slesvig*. Desværre vides det ikke, om en udtrykkelig autorisation har foreligget, eller om en af de talløse danske 
Balslev-udgaver har været trykt på sønderjysk grund på ministeriets foranledning eller endda har været udstyret med privilegium for de sønderjyske vajsenhuse.

Den danske Balslev blev også brugt $\mathrm{i}$ sprogreskripternes område $\mathrm{i}$ Mellemslesvig i det nuværende Sydslesvig. Lærer Peter Lasthein nævner udtrykkelig, at Harreslev skole i Hanved sogn var vel forsynet med Balslevs bøger, og 1852 tilsendte det kongelige amtshus i Flensborg skolen bl. a. 60 bibelhistorier. L. S. Ravn har fundet både bibelhistorien og katekismen nævnt blandt de skolebøger, der var $\mathrm{i}$ brug ved langt de fleste skoler, så de må regnes for nærmest enerådende i de blandede distrikter.

1859-udgaven af katekismen er "neu übersetzt «, og det vil altså sige, at man ikke har brugt Grüns oversættelse. Den var endda forbedret af Asschenfeldt, som var en erfaren digter $i$ det tyske sprog, og som altså skulle være kyndig både som teolog og som sprogmand. Vi kender ikke ministeriets grund til at vrage Grün, og oversætteren er ikke angivet på titelbladet, men vi ved, at biskop U. S. Boesen i 1859 betalte de to lærere Glüsing og Nissen et honorar på 300 rdlr. for oversættelsen af katekismen. Det er ikke helt uinteressant, hvordan man kvitterede dengang, og derfor hidsætter vi ordlyden:

An Honorar für die Übersetzung des Lehrbuchs von Sr. Hochehrwürden dem Herrn Stiftspropsten Balslev in Ribe * Luthers Katechismus med en kort Forklaring * ist uns Unterzeichneten von Sr. Magnificenz dem Herrn Bischof Boesen zu gleicher Teilung die Summe von 300 Rthlern: Drei Hundert Rthlern hochgeneigtest ausbezahlt worden, wofür wir hiermit ehrfurchtsvoll dankend quittieren.

Flensburg, den 28. Februar 1859.

\section{H. J. Glüsing \\ F. Nissen}

Grün fik dog ingen grund til klage, hvad man kan se af et brev til biskoppen og en kvittering:

\section{Højvelbaarne, bøjervardige Herr Biskop! .}

Igaar modtog jeg Drs Højærværdigheds Skrivelse af 27. f. M. Saa er mit glade Haab altsaa ikke blevet skuffet, og modtager Drs Højxrværdighed hermed min dybeste Tak, som jeg ved Nidkærhed i 
mit Embede og i min hele Opførsel skal beflitte mig paa ogsaa at vise i Gjerninger.

Jeg sender Brevet til min Svoger Schlesinger og anmoder ham om at modtage Beløbet, imod at han selv afleverer Brevet.

Deres Højærværdigheds lydige og taknemmelige

P. C. Grün.

Nørrefarensted, den 3. Marts 1859.

Der var langt fra Nørre Farensted til bispekontoret i Flensborg. Man var den gang vant til at gå langt, og kun rige folk kørte eller red. Offentlige færdselsmidler fandtes næsten ikke, og postvæsenet kendte kun byerne. Det er baggrunden for, at Grün overlader det til svogeren, degn og lærer C. E. L. Schlesinger i Adelby tæt uden for Flensborg, at hente pengene. Han har så medbragt følgende

\section{Qvittering}

At der af Hs. Højærværdighed Herr Biskop Boesen R. a. D. i Flensborg idag er udbetalt mig imod denne Qvittering

Et Hundrede Rigsdaler R. M.

som en overordentlig Gratification bevidner jeg herved med dybeste Tak.

P. C. Grün,

Nørrefarensted, d. 4. marts 1859.

Degn og Skolelærer.

Sammenfaldet $\mathrm{i}$ tid med udbetalingen til Glüsing og Nissen gør det rimeligt at antage, at gratifikationen skal holde Grün skadesløs både på sjxlen og pungen for det tab, der blev påført ham ved, at han ikke længere kunne gøre sig håb om at se sin katekismus udkomme. Nutids mennesker stødes umiddelbart ved den noget servile tone $\mathrm{i}$ de tre læreres breve og kvitteringer, for man finder oprørere mere mandige end tro tjenere, men også troskab og nidkærhed har sin rejsning.

De to lærere var kendt som dygtige pædagoger, og de har forfattet flere lærebøger. Det klarlagte forhold om katekismen gør det troligt, at de også er oversætterne af 1858-udgaven af bibelhistorien, men derom foreligger der intet sikkert.

Hans Jürgen Glüsing var født i Flensborg den 19. september 1812. I Jan blev uddannet som lærer på Skårup seminarium og var siden lærer ved et drengeinstitut i Fåborg 1837-41 og dernæst ved real- 
skolen i samme by til 1850. Han har altså været særdeles fortrolig med dansk, og dette blev ikke ringere af, at han giftede sig med en af byens piger, en datter af købmand Sander. I 1850 blev han skrive- og regnemester i Flensborg, og dette tidspunkt ser ud som en tanke. I Flensborg havde man brug for nationalt pålidelige folk, og Glüsing har nxppe været ked af at få en bedre stilling oven $\mathrm{i}$ købet i sin førleby. Han blev førstelærer ved drengeskolen i Flensborg i 1870 og gik af med pension i 1881 og døde kort efter, den 21. januar 1882. Selv udgav han i 1852 et "Skriveapparat $i$ Flensborg, og sammen med Friedrich Nissen udgav han Erstes Lesebuch. Zunächst für die Elementarclassen der vaterländischen Volksschulen «, Flensborg 1857.

Friedrich Nissen var født i Frederiksstad den 1. februar 1820 og blev gift med organist Peters datter i Neuenkirchen. Han fik sin uddannelse på Tønder seminarium med eksamen i 1842. Bortset fra et kort ophold i Ảbenrå virkede han i tysktalende egne, indtil han i 1853 blev lærer ved friskolen i Sankt Marie sogn i Flensborg, hvor han døde i 1884. Intet tyder på en særlig kyndighed i dansk, men man bør ikke overse, at dansk var undervisningsgenstand på Tønder seminarium, og undervisningen var ganske grundig, så helt ukendt med sproget har han næppe været. Men det kan jo også tænkes, at de to oversættere har delt arbejdet, så at Glüsing sørgede for den rette forståelse af den danske tekst, og Nissen tog sig af det tyske udtryk.

Balslevs bøger var et uhyre pædagogisk fremskridt. De hører hjemme i en lang række korte fremstillinger af forskellige videnskabs- og sagområder, som danske forfattere har gjort sig europxisk kendte og agtede ved, lige siden bogtrykkunsten blev taget $\mathrm{i}$ brug. Med 1864 forsvandt Balslevs danske bøger straks fra sprogreskripternes område i det nuværende Sydslesvig. Her var de overflødige, da skolen ikke gav ly for så meget som én times dansk religionsundervisning. I Nordslesvig forsvandt de også. Ved provstivisitatsen i Varnæs kirke 2. pinsedag forbød Bertel Godt, som nu var hovedprest i Broager og provst i Sønderborg-Abenrå provsti, Balslevs katekismus, men sognemændene ytrede som med én mund, at de ønskede at beholde lærebogen. Provsten ville ikke ud med grunden til, at Balslev skulle forbydes. En bonde bemærkede, at det vel var, fordi der står i den, at »mened er en gruelig og formastelig misbrug af Gud navn«, men 
"det er muligt, at hr. Godt ikke hørte denne bemærkning «, slutter "Fædrelandet« sin beretning 30. maj 1864. Den 17. juni meddeler bladet, at Tønder provstis kirkevisitatorium, d. v. s. amtmand og provst, nylig har udsendt et cirkulære fra den fungerende generalsuperintendent Johannes Andreas Rehhoff, hvori præster og skolelærere opfordres til en "gesinnungs «-dygtig virksomhed. Balslevs lærebog, Rimestads og Barfods geografiske og historiske lære- og læsebøger forbydes i skolen, og endelig gengiver bladet den 28. juni et cirkulære fra Rehhoff: alle provster i Slesvig har forlangt, at så vel Cramers om Balslevs katekimus - den danske original og den tyske oversættelse - afskaffes, og derfor bør disse ikke længere bruges i skolen.

Balslevs bøger blev lagt for had af den tyske propaganda længe før 1864. Den kaldte dem "Ballsleef " efter det plattyske ord for den store bolleslev, som man laver boghvedeboller med, men alligevel undrer man sig ikke så lidt over, at en ren og skær religiøs bog som Balslevs katekismus falder som offer for en politisk handling. Og det bliver jo ikke bedre af, at J. A. Cramers omtrent 100-årige "LandesCathechismus" gik med i løbet.

Bertel Godt blev senere venligere mod det danske sprog, og helt så galt som generalsuperintendenten og provsterne prxdikede, gik det heller ikke. Omkring 1865 henvendte lærer Lauesgaard i Sillerup, Fjelstrup sogn, sig til provst Prahl i Gammel Haderslev og spurgte, hvad han skulle gøre. Han ville gerne beholde Balslevs lærebog. Provst Prahl svarede, at det kunne han roligt gøre, for provsten brugte selv med den største glæde Balslevs katekismus.

\section{NOTER}

Kilder: De nævnte Balslev-udgaver findes alle i Statsbiblioteket i Århus. Grün: Das Vaterland, 1854, findes i Dansk Centralbibliotek, Flensborg. Kvitteringer fra Glüsing, Nissen og Grün samt den sidstes brev findes i Landsarkivet i Åbenrå: Slesvigsk Biskop-Arkiv nr. 25-36 (nr. 36). Dem har L.S. Ravn overladt mig afskrifter af, og artiklen er $i$ øvrigt fremgået af længere tids samarbejde med L. S. Ravn, som jeg takker for. Glüsings levned findes i Personalhistorisk Tidsskrift 69, årg. 1948 s. 50, ved Aage Bonde. Peter Lastheins erindringer i Sydslesvigsk Kirkekalender 1950 er optrykt i L. S. Ravn: Lærerne under sprogreskripterne 1851-64, 1971. Hejselbjerg Paulsen har fortalt mig om provst Prahl. C. F. Balslevs billede fra Det kongelige Bibliotek, P. C. Grüns venligst fra Kurt Grün. Kopier i Dansk Centralbibliotek, Flensborg. 